\title{
Study Questions for the Certified Pesticide Applicator Examination: Natural Areas Weed Management ${ }^{1}$
}

Ken A. Langeland ${ }^{2}$

The following questions are intended to help prepare you for taking the Natural Areas Weed Management Certified Pesticide Applicator Examination. It should be used along with IFAS publications SP 295 Natural Area Weed Management - A Training Manual for Restricted Use Pesticide Applicators and SP 257 Identification \& Biology of Non-Native Plants in Florida's Natural Areas, which can be obtained from the IFAS Extension Book store by calling 800-226-1764 (local 359-392-1764) or from http://ifasbooks.ufl.edu. For some questions you will need a copy of a Garlon 4 herbicide label, which can be obtained from http://www.cdms.net/manuf/manuf.asp. Answers to all questions can be found in these publications. You will greatly improve your ability to achieve a passing examination score by locating the answers to the study questions and writing them down.

1. This document is SS-AGR-255, one of a series of the Agronomy Department, Florida Cooperative Extension Service, Institute of Food and Agricultural Sciences, University of Florida. Published August 2005. Please visit the EDIS Web site at http://edis.ifas.ufl.edu.

2. K. A. Langeland, professor, Agronomy Department, Center for Aquatic and Invasive Plants; Florida Cooperative Extension Service, Institute of Food and Agricultural Sciences, University of Florida, Gainesville, FL 32611.

The use of trade names in this publication is solely for the purpose of providing specific information. UF/IFAS does not guarantee or warranty the products named, and references to them in this publication does not signify our approval to the exclusion of other products of suitable composition. 


\section{Chapter 1}

What is the similarity between the terms weed and invasive plant?

What is different between the definitions of weed and invasive plant?

List five control methods that may be coordinated into an integrated pest management (IPM) program.

\section{Chapter 2}

Name three plant lists that have legislative authority.

What is the best method to obtain a positive identification on a new weed species and provide a record of its occurrence? 


\section{Chapter 3}

Relative to solubility, what is the main difference between herbicide active ingredients with polar, i.e. salts of acid herbicides, molecules compared to those with non-polar, i.e. esters, molecules?

List two non-polar herbicide active ingredients and five polar herbicide active ingredients.

$\underline{\text { Non-polar (esters) }} \quad \underline{\text { Polar (salts of acids) }}$

What is the name of the outer layer of a leaf that herbicide mast pass through to enter the plant and what are three components of this layer, which are barriers to herbicide absorption associated with this layer?
$\underline{\text { Layer }}$
$\underline{\text { Components }}$

What is the term that describes the most important factor that affects herbicide uptake from soils?

What is the term that is used to describe uptake of herbicides by plant roots? 
Draw a cross section of a woody (dicot) plant stem and show the location of the living tissue.

List four plant processes that are affected by herbicides (herbicide mode of action).

Herbicides with which mode of action require additional record keeping under Florida Pesticide Law (core training)?

What is the term used for a herbicide that can be use for broadcast application and kill a target weed and not certain non-target plants that it comes in contact with?

List three application methods that can be used to selectively control target vegetation.

List five methods to reduce drift.

List five factors that adversely affect herbicide activity. 
List four ways in which herbicides can disappear from soil.

List five ways in which herbicides may be deactivated once absorbed by plants.

\section{Chapter 4}

List two circumstances under which a broadcast herbicide application may be used.

What characteristic do all herbicides that are used for basal bark application have in common?

How quickly after felling a tree should herbicide be applied to the stump to optimize control?

What special care should be taken to prevent non target damage when applying soil active herbicides?

\section{Chapter 5}

What must be listed on a herbicide label so that it can be legally applied to a particular site?

What state agency should you contacted for legal interpretation of label instructions?

What state agency issues permits for control of aquatic plants? 
When applying a herbicide to control an invasive plant species on a site that is allowed by Special Local Need registration (SLN), what must the applicator have and where should this be?

Consider the following list of herbicide active ingredients as indicated:

2,4-D

glyphosate

hexazinone

imazapyr

metsulfuron

triclopyr

Which are likely to be absorbed by plant roots.

List under the appropriate Mode of action:

$\underline{\text { Auxin interference }} \quad \underline{\text { Amino acid (protein) syntheses inhibitor }} \quad \underline{\text { Photosynthesis inhibitor }}$

Which are likely to leach:

Which have the greatest persistence: 


\section{Chapter 6}

Who does the "Worker Protection Standard" (WPS) referred to on pesticide labels pertain to?

Why is diesel fuel not recommended as a herbicide diluent for use in natural areas?

List two types of surfactants and how they modify performance of a herbicide solution applied to a leaf surface.

List three ways by which the use of colorants can be helpful to a herbicide application.

How many ounces of herbicide product are needed to prepare 4 gallons of spray solution if the herbicide label requires mixing 20 gallons of product per 100 gallons of spray solution? 
How many ounces of herbicide solution are needed to prepare 4 gallons of $1.5 \%$ spray solution?

How many gallons of spray mix would be applied per acre if 60 ounces are applied to $400 \mathrm{sq} \mathrm{ft}$ ?

How many ounces of liquid herbicide product should be added to a 3-gallon spray tank to apply 7 pints of product per acre for a sprayer that delivers 167 gallons per acre?

How much ultra low weight granular herbicide product is required to treat an area that measures $270 \mathrm{ft}$ by $470 \mathrm{ft}$ at a rate of 2 pounds product per acre? 
For the following question refer to: "Identification and Biology of Non-Native Plants in Natural Areas of Florida"

Match the following non-native plants with the characteristics that best describe them.

Australian pine

Brazilian pepper

Melaleuca

Old World climbing fern

Japanese climbing fern

1. Climbing fronds with pinnae that are often twice compound.

2. Wiry rhizomes, climbing fronds, pinnae once compound.

3. Soft, whitish, peeling, bark.

4. Evergreen shrub or tree, leaves alternate, odd-pinnately compound.

5. Evergreen tree to 150 feet tall with needle-like branchlets.

For the remaining questions refer to a Garlon 4 label, which can be obtained from http://www.cdms.net/manuf/manuf.asp.

How many pounds of triclopyr, expressed as acid equivalent, are contained in one gallon of Garlon 4?

What PPE must be worn by an applicator who is applying Garlon 4 to control an invasive plant in a natural area?

What should not be done if Garlon 4 is swallowed?

What precautions must be made with respect to bodies of water when using Garlon 4 ? 
What is the maximum rate of Garlon 4 that can be applied to a conservation land where cattle (other than lactating dairy animals) are allowed to graze with no grazing restrictions?

What is the maximum use rate of Garlon 4 ?

What is the maximum percent concentration of Garlon 4 that can be used to control woody plants with "foliar treatment with ground equipment" and "high volume foliar treatment?"

What is the maximum percent concentration of Garlon 4 that can be used to control woody plants with foliage when using "broadcast applications with ground equipment?"

Give two differences between "basal bark treatment" and low volume basal bark treatment." 